\title{
The Role of IL-10 in Atherosclerosis
}

\author{
Xinbing $\operatorname{Han}^{1}$ and William A. Boisvert ${ }^{2}$ \\ ${ }^{1}$ Department of Medicine, Beth Israel Deaconess Medical Center, \\ Harvard Medical School, Boston, MA, \\ ${ }^{2}$ Center for Cardiovascular Research, John A. Burns School of Medicine, \\ University of Hawaii, Honolulu, HI, \\ USA
}

\section{Introduction}

Cardiovascular diseases, including coronary artery disease (CAD), ischemic gangrene, abdominal aortic aneurysms, and many cases of heart failure and stroke currently account for the most number of deaths in the Western world (Hansson et al., 2006). The root cause of these diseases is atherosclerosis, which is widely accepted these days to be a chronic inflammatory disease in addition to the more recognized disorder of lipid metabolism. Although it was established long ago that high levels of low-density lipoprotein (LDL) cholesterol is a major risk factor for atherosclerosis, more recently both innate and adaptive immune systems have been accepted as major participants in the initiation and progression of atherosclerosis. Besides monocytes/macrophages, $\mathrm{T}$ cells and dendritic cells (DCs) can be detected within atherosclerotic lesions and have been implicated in the pathogenesis of atherosclerosis (Hansson and Libby, 2006) (Weber et al., 2008). Atherosclerotic lesion progression has been shown to depend on ongoing, chronic inflammation in the artery wall. Following hyperlipidemia, a rapid influx of circulating monocytes into the atherosclerosis-prone areas of the arterial intima occurs. These recruited inflammatory monocytes differentiate into macrophages and take up modified atherogenic cholesteryl ester (CE)- rich lipoproteins in the intima of the vessel wall (Lusis, 2000) (Ross, 1999) (Wang and Tall, 2003). The accumulation of cholesterol-loaded macrophages in the arterial wall called "foam cells" is a key feature of early atherosclerotic lesions (Brown and Goldstein, 1983).

Upon lipid uptake within the artery wall, macrophage foam cells activate a compensatory pathway for cholesterol efflux, mediated by the ATP-binding cassette (ABC) transporters ABCA1 and ABCG1 (Wang et al., 2007). During systemic hypercholesterolemia, however, this homeostatic mechanism is overwhelmed, leading to the accumulation of foam cells and the initiation of fatty streak lesions. The importance of these transporters is illustrated by the fact that a combined deficiency of ABCA1 and ABCG1 accelerates foam cell accumulation and atherosclerotic development in mice (Yvan-Charvet et al., 2007). Cholesterol loading of macrophages also stimulates the production of inflammatory mediators, which recruit other cell types and contribute to the development of a complex lesion (Hansson et al., 2002). Thus, processes that interfere with the intracellular cholesterol balance would be expected to exacerbate lesion formation. 
Cholesterol is an essential structural component in the cell membrane and a precursor for steroid hormone and bile acid synthesis in metabolic pathways. Thus, cholesterol homeostasis needs to be strictly regulated. The intracellular cholesterol concentration is tightly controlled by feedback mechanisms that operate at both transcriptional and posttranscriptional levels (Brown and Goldstein, 1997). For example, the liver X receptor (LXR), belonging to the family of nuclear hormone receptors, contributes to cholesterol homeostasis by activating the transcription of genes involved in the response to cholesterol excess, including ABCA1 and ABCG1 (Beaven and Tontonoz, 2006). These transporters promote cellular cholesterol efflux to high-density lipoprotein (HDL) and its associated apolipoprotein (apo)-A1, a crucial step in the initiation of reverse cholesterol transport (RCT) to the liver for excretion (Tall et al., 2008). Other ways in which lipid-loaded and activated macrophage foam cells can significantly contribute to the maintenance and progression of atherogenesis is by producing nitric oxide, reactive oxygen species, inflammatory lipids, growth factors, and pro-inflammatory cytokines such as interleukin (IL) -1, IL-6, interferon (IFN)- $\gamma$ and tumor necrosis factor (TNF)- $\alpha$ (Hansson, 2001). Taken together, alterations in both lipid metabolism and the immune responses in macrophages play a significant role in promoting the development of atherosclerotic lesions. Knowledge of the mechanisms that regulate these responses could therefore be of considerable value with respect to the development of new approaches to prevention and treatment.

As a prototypic anti-inflammatory cytokine, IL-10 is made primarily by the macrophages and $\mathrm{T}$ lymphocytes of the Th2 subtype. Its major functions include inhibition of macrophage activation as well as inhibition of MMP, pro-inflammatory cytokines and cyclooxygenase-2 expression. IL-10 induces the proliferation of mast cells, B and T lymphocytes, and enhances T cell response to IL-2. Although it is clearly documented that IL-10 is expressed in the atherosclerotic plaque (de Vries, 1995) (de Waal Malefyt et al., 1991) (Gerard et al., 1993) it is not fully understood how IL-10 influences the atherogenic process. This chapter will highlight the current knowledge about the role of IL-10 in the initiation and progression of atherosclerosis. Inasmuch as macrophages play a critical role in the pathogenesis of atherosclerosis, the review will focus largely on how IL-10 stimulates and regulates the activities of macrophages that are important in the development of atherosclerosis.

\section{Anti-atherogenic properties of IL-10}

IL-10 exerts its atheroprotective effect on plaque progression, rupture, or thrombosis throughout the different stages of atherosclerosis by influencing the local inflammatory process within the atherosclerotic lesion. As an anti-inflammatory cytokine IL-10's atheroprotective effects are exerted mainly by inhibiting various cell processes including the production of inflammatory mediators, matrix metalloproteinases (MMPs) and tissue factor (TF) production, and apoptosis. IL-10 is produced predominantly by macrophages within the local atherosclerotic lesion where it could play a significant role in the modulation of the local inflammatory response for both macrophages and $\mathrm{T}$ cells.

\subsection{Influence on macrophage function}

Macrophages play a central role during all stages of atherosclerosis (Moore and Tabas, 2011). Early in vivo studies using immunochemistry and PCR have indicated that macrophages in atherosclerotic lesion are the main source of IL-10 production in advanced atherosclerotic plaques (Mallat et al., 1999b). IL-10 plays an essential role in down-modulating adaptive and 
innate immune responses, partly by inhibiting the activation of human monocytes and monocyte-derived dendritic cells (Woszczek et al., 2008).

Atherogenesis is initiated with the recruitment of inflammatory cells to the intima. Following inflammatory activation, the recruited monocytes are differentiated into macrophages which take up modified LDL particles such as oxidized LDL (oxLDL), through scavenger receptors, thereby promoting cholesterol loading and foam cell formation in the plaque's core. Lipid-laden macrophages produce multiple pro-inflammatory mediators, reactive oxygen species (ROS), and TF pro-coagulant that promote local inflammation and promote thrombotic complications. The paradigm that macrophages play a critical and definitive role in human atherosclerosis has been evidenced by a large number of publications from various studies of experimental atherosclerosis. The morphological observation that macrophages are abundantly distributed from early stage lesion in fatty streak to the late stage within fibrous plaques indicates; macrophage-derived foam cells are absolutely critical for development of atheromas (Libby et al., 2011) (Little et al., 2011).

The mechanisms by which IL-10 may protect against atherogenesis can be categorized, albeit artificially, into 4 aspects of macrophage function: 1 . anti-inflammatory properties 2 . inhibition of MMPs and TF 3. anti-apoptotic feature 4. modulation of lipid metabolism.

\subsubsection{Anti-inflammatory properties of IL-10}

Atherosclerosis is a chronic inflammatory condition of the arterial wall characterized by progressive accumulation of lipids, cells (macrophages, T lymphocytes, and smooth muscle cells), and extracellular matrix (Ross, 1999) (Libby et al., 2011) (Charo and Taub, 2011) (Maskrey et al., 2011). During recent years, inflammation has emerged as a major driving force in atherosclerotic lesion development throughout the different stages of the disease (Libby et al., 2011) (Charo and Taub, 2011) (Moubayed et al., 2007) (Little et al., 2011), from early fatty streak to advanced fibro-fatty plaque formation. Of the cells participating in atherogenesis, monocyte-derived macrophages and T-lymphocytes are the most prominent cells that secrete various pro- or anti-atherogenic cytokines that can influence the disease development and affect plaque stability (Ferri et al., 2009) (Pasqui et al., 2006) (Kleemann et al., 2008) (Galkina and Ley, 2009) (Woollard and Geissmann, 2010) (Weber et al., 2008).

Being the most abundant inflammatory cell type in the plaque, macrophages are the most important source of cytokine production in atherosclerotic lesions (Tedgui and Mallat, 2006) and can produce pro-inflammatory cytokines such as TNF- $\alpha$, IL-1, IL-6, IL-12, IL-15, IL-18, as well as the anti-inflammatory cytokines like IL-10 and transforming growth factor- $\beta$ (TGF- $\beta$ ). It has been well documented that pro-inflammatory cytokines can promote development of atherosclerosis (Little et al., 2011) while anti-inflammatory cytokines like TGF- $\beta$ (Bobik et al., 1999) and IL-10 (Nishihira et al., 2006) can have an anti-atherogenic effect.

One of the earlier studies showed that IL-10 mRNA was detected by RT-PCR in 4 of 5 human atherosclerotic specimens but not in plaque-free aortic specimens (Uyemura et al., 1996). When human monocytes isolated from PBMC were incubated with oxLDL, IL-10 protein production was increased (Uyemura et al., 1996). The presence of IL-10 in advanced human atherosclerotic plaque was subsequently verified by another group (Mallat et al., 1999b). They showed also by using RT-PCR, that IL-10 mRNA was present in 12 of 17 atherosclerotic plaques, mainly in macrophages (Mallat et al., 1999b). These studies suggest that progressive inflammation during atherosclerosis causes macrophages to express IL-10. 
IL-10 is a potent anti-inflammatory cytokine. Increased IL-10 serum level is a beneficial prognostic determinant in patients with acute coronary syndromes (Heeschen et al., 2003). A line of publications has shown that IL-10 expression by plaque macrophages limits the inflammatory response and promotes plaque healing (de Vries, 1995) (de Waal Malefyt et al., 1991) (Gerard et al., 1993) by inhibiting IL-12 (Uyemura et al., 1996) and inducible nitric oxide synthase (iNOS) production (Mallat et al., 1999b) (Ito and Ikeda, 2003). Attenuation of atherogenesis by IL-10 was attributed to its anti-inflammatory effects, most notably its ability to inhibit the release of several pro-inflammatory cytokines (including IL-1 $\beta$, TNF- $\alpha$, and IL-8) from monocytic cells, and to induce the production of IL-1 receptor antagonist (Terkeltaub, 1999) (van der Poll et al., 1994) (Wang et al., 1995). IL-10 also suppresses the production of the chemokine KC/GRO- $\alpha$ (Kishore et al., 1999) which is implicated in intimal macrophage accumulation and the progression of complex atherosclerotic lesions in advanced disease (Boisvert et al., 1998). MCP-1 is chemotactic for monocytes and highly expressed in macrophage-rich areas of the lesion. IL-10-induced inhibition of MCP-1 (Ajuebor et al., 1999) (Han et al., 2009) (Han et al., 2010) (Zimmerman et al., 2004), a key player in monocyte recruitment to early atherosclerotic lesions (Gosling et al., 1999), has been regarded as an important protective mechanism of atherogenesis by IL-10.

\subsubsection{Inhibition of matrix metalloproteinases and tissue factor}

Pathological studies have provided evidence that extracellular matrix content and its degradation are related to vulnerability and instability of plaques (Libby, 1995). It has been well documented that clinical instability of atherosclerosis is related to the activation of local inflammatory and immune cells with increased expression of MMPs (Libby, 1995) and TF (Ardissino et al., 1997) in the culprit plaque as well as increased systemic production of MMPs (Kai et al., 1998) and thrombin (Biasucci et al., 1996) (Caligiuri et al., 2003). Macrophages are important sources of MMPs within atherosclerostic lesions, including MMP-2, MMP-8, MMP-9, MMP-12, MMP-13, and MMP-14 (Gough et al., 2006) (Little et al., 2011). MMPs affect lesion development and progression by degrading extracellular matrix proteins, leading eventually to the development of unstable, rupture-prone atherosclerotic lesions (Boyle, 2005) (Little et al., 2011). Tissue factor is a prothrombotic molecule expressed by various cell types within atherosclerotic plaques and has been thought to play an essential role in thrombus formation after atherosclerotic plaque rupture (Kamimura et al., 2005). There is evidence that IL-10 may have protective effects against plaque rupture and thrombus formation (Waehre et al., 2002). IL-10 can inhibit the secretion of MMPs (Waehre et al., 2002) (Han et al., 2009) (Han et al., 2010) (Holven et al., 2006), the synthesis of TF (Kamimura et al., 2005) (Ramani et al., 1993), and the production of thrombin (Pajkrt et al., 1997) from PBMC and macrophages. Decreased collagen synthesis and increased activity of macrophage-derived matrix degrading metalloproteinases are responsible for fibrous cap thinning and fragility. Therefore, low levels of IL-10 may lead to augmented MMP activity which may in turn promote plaque instability to cause acute cardiovascular events in certain individuals (Holven et al., 2006) (Mallat et al., 1999a). In addition, the balance between Th1 (IFN- $\gamma$ ) and Th2 (IL-10) polarization in T helper cells may play an important role in atherogenesis. IFN- $\gamma$ may destabilize plaques not only by inhibiting collagen production (Amento et al., 1991) in human vascular smooth muscle cells, but by stimulating MMP production in macrophages (Libby, 1995) (Saren et al., 1996) and modulating the fibrinolytic response of endothelial cells (Arnman et al., 1995) (Gallicchio et al., 1996). 


\subsubsection{Anti-apoptotic properties}

Both IL-10 transgenic animal models and mice deficient in either IL-10 or IL-10 receptor have highlighted the anti-apoptotic feature of IL-10. Both apoptosis and necrosis occur in the atherosclerotic plaque (Geng and Libby, 1995) (Isner et al., 1995) (Han et al., 1995) (Bjorkerud and Bjorkerud, 1996; Cai et al., 1997; Geng and Libby, 1995; Han et al., 1995; Isner et al., 1995). IL-10's anti-apoptotic properties have been reported in cultured macrophages (Arai et al., 1995) (Han et al., 2009) (Han et al., 2010) and in T lymphocytes (Cohen et al., 1997). Inflammatory nitric oxide has apoptotic effects (Geng et al., 1996) (Albina et al., 1993) and can induce cell death, at least in part through local peroxynitrite formation (Luoma et al., 1998) (Kockx et al., 1998). One mechanism by which IL-10 can protect from excessive cell damage and death in the plaque is by inhibition of iNOS production (Cattaruzza et al., 2003). The production of ROS is increased in atherosclerotic arteries (Minor et al., 1990), leading to endothelial damage, oxidation of lipid components (Witztum and Steinberg, 2001), and recruitment of inflammatory cells to the site of injury. IL-10 may down-regulate immune responses in atherosclerosis by inhibiting antigen presentation to T cells (de Waal Malefyt et al., 1991), and by inhibiting production of reactive oxygen intermediates which result in oxidation of LDL (Bogdan et al., 1991). In addition, IL-10 activates signal transducer and activator of transcription 3 (STAT3), which suppresses endoplasmic reticulum (ER) stress-induced apoptosis in macrophages by inducing the expression of cell-survival molecules (Li et al., 2008). The increased expression of the anti-apoptotic genes Bfl-1 and Mcl-1 in response to IL-10 contributes to the suppression of apoptosis by IL-10 in lipid-laden foam cells (Halvorsen et al., 2005). Furthermore, because excessive accumulation of free cholesterol can cause apoptosis in cells, one other way in which IL-10 may exert its antiapoptotic effects is by stimulating ABCA1/ABCG1 production which increases the cholesterol efflux from lipid laden foam cells (Rubic and Lorenz, 2006) (Han et al., 2009) (Han et al., 2010).

\subsubsection{Polarization of macrophage by IL-10}

In response to cytokines and microbial products, macrophages have the ability to be polarized into one of two subgroups: classically activated M1 and alternatively activated M2 form (Benoit et al., 2008). The concept of macrophage polarization has been widely accepted in recent years (Mantovani et al., 2005) (Martinez et al., 2008). M1 macrophages are induced by IFN- $\gamma$, microbial stimuli (e.g. LPS) or cytokines such as TNF-a and GM-CSF. M2 macrophages are induced by IL-4, IL-10, IL-13, immune complexes, glucocorticoid or secosteroid (vitamin D3) hormones (Mantovani et al., 2005; Martinez et al., 2008). One of the notable features of M1 macrophage is its low level of IL-10 expression and high levels of IL12 and IL-23 expression. As efficient producers of reactive oxygen and nitrogen intermediates and inflammatory cytokines, M1 macrophages are associated with protection during acute infectious diseases, and can induce and polarize Th1 response as well as mediate immune response against intracellular parasites and tumors (Benoit et al., 2008).

By contrast, M2 macrophage phenotype is characterized by abundant expression of IL-10 and low levels of IL-12 and IL-23 production. By expressing high levels of scavenger, mannose and galactose-type receptors, M2 macrophages participate in polarized Th2 response and exert immunoregulatory functions (Martinez et al., 2008) (Mantovani et al., 2005) by promoting killing and encapsulation of parasites (Noel et al., 2004). They are actively involved in tumor progression, tissue repair and remodeling (Wynn, 2004). Chronic 
infectious diseases are associated with macrophage reprogramming towards an M2 profile (Benoit et al., 2008).

Both M1 and M2 macrophages are present in atherosclerotic lesions (Khallou-Laschet et al.). Exposure of macrophages to oxLDL renders M2 macrophages pro-inflammatory (van Tits et al., 2011). Compared with pro-inflammatory M1 macrophages, anti-inflammatory M2 macrophages are more susceptible to foam cell formation (van Tits et al., 2011). Interestingly, however, a recent report indicates that M2 phenotype may exert an atheroprotective action in experimental atherosclerosis (Khallou-Laschet et al.). On the other hand, PPARY activation plays an essential role in promoting polarization of circulating blood monocytes to become M2 macrophages (Bouhlel et al., 2007) (Charo, 2007) (ChinettiGbaguidi and Staels). Convincing clinical evidence and animal experiments from PPARYdeficient mice and from the mice treated with PPARY ligands have demonstrated the beneficial role of PPARY activation in preventing atherosclerosis (Staels, 2005) (Ricote et al., 1998). Because IL-10 increases ABCA1-mediated cholesterol efflux through PPARY activation (Han et al., 2009) (Han et al., 2010), it is likely that PPAR $\gamma$-driven M2 macrophage formation plays an important role in athero-protective action by IL-10.

\subsubsection{Modulation of lipid metabolism}

The loading of macrophages with lipoprotein-derived cholesterol alters macrophage functions during atherogenic processes. The fact that IL-10 production is increased in lipid laden macrophages suggests that IL-10 may be involved in lipid metabolism in these cells. In fact, oxLDL can promote immune activation by inducing pro-inflammatory cytokines IL-12 and TNF- $\alpha$, and anti-inflammatory cytokine IL-10 production by mononuclear leukocytes from human atherosclerotic plaque (Fei et al., 2003). During recent years, the involvement and importance of IL-10 in lipid metabolism, particularly in macrophages, has been increasingly recognized.

With regard to lipid metabolism and foam cell formation, two steps are critical in maintaining lipid homeostasis in macrophages: 1. cholesterol uptake mediated by scavenger receptors and 2. cholesterol efflux mediated by ABCA1/ABCG1. Scavenger receptors such as scavenger receptor $\mathrm{A}$ and $\mathrm{CD} 36$ on macrophages mediate the uptake of modified lipoproteins from the vessel wall (Nagy et al., 1998). In addition, reverse cholesterol transport through ABCA1 and ABCG1 is an important mechanism to export cytotoxic cellular free cholesterol to lipid poor apoAI and lapidated HDL particles (Chinetti et al., 2001; Kennedy et al., 2005) . It is well documented that cholesterol efflux via ABCA1 and ABCG1 is essential to slow the development of atherosclerosis by decreasing lipid loading (Yvan-Charvet et al., 2007) (Zhao et al., 2010) (Calkin and Tontonoz, 2010) (Fitzgerald et al., 2010) (Ye et al., 2011). Although the role of scavenger receptors appears complicated because of conflicting results from gene knockout or transgenic mouse studies (Hansson and Hermansson, 2011) the general consensus among recent publications is that these receptors are protective against atherosclerosis due to their ability to remove modified LDL from the vessel wall (Marleau et al., 2005) (Moore et al., 2005) (Van Eck et al., 2000) (Whitman et al., 2002) (Liao et al., 2000) (Teupser et al., 1999).

Recent in vivo results show that the role of IL-10 in regulating lipid metabolism remains elusive. Plasma lipoprotein levels including LDL, HDL and triglyceride have been measured in these animal models but the results appear controversial and are dependent on several factors such as the animal model used, route of administration and stage of atherosclerosis 
investigated. In C57BL/6J mice, total plasma cholesterol and HDL cholesterol levels were not affected by IL-10 deficiency (Mallat et al., 1999a) (Pinderski Oslund et al., 1999). Systemic IL-10 overexpression lowered plasma VLDL and LDL cholesterol levels in LDLR-/- mice (Von Der Thusen et al., 2001), but IL-10 overexpression in T cells did not alter circulating lipoprotein profiles (Pinderski et al., 2002). No changes in plasma (Namiki et al., 2004) or reduced cholesterol levels (Yoshioka et al., 2004) were observed in apoE-/- mice with intramuscular gene transfer of IL-10 cDNA. Interestingly, the lack of IL-10 led to increased LDL cholesterol whereas VLDL was reduced in apoE-/- mice with no significant changes observed in either total cholesterol or triglyceride levels (Caligiuri et al., 2003). However, systemic delivery of adeno-associated virus type 2-hIL-10 inhibited atherogenesis in LDLR knockout mice with no changes in plasma cholesterol levels (total cholesterol, LDL, HDL, and TG) compared with those with no treatment (Liu et al., 2006). In APOE*3-Leiden mice, IL-10 deficiency did not lead to significant changes in cholesterol levels but overexpression of IL-10 reduced cholesterol levels after feeding a high-fat, cholesterol-rich diet (Eefting et al., 2007). These confusing set of results suggest that IL-10-modulated lipid metabolism and plasma cholesterol levels vary widely and is dependent on the animal models utilized. The role of IL-10 in lipid metabolism needs to be rigorously elucidated, especially in relation to human atherosclerosis.

Recent publications provide convincing evidence that IL-10 can modulate cellular lipid metabolism, including cholesterol uptake and cholesterol efflux (reverse cholesterol transport). In 2005, Halvorsen et al. reported that IL-10 enhances oxLDL-induced formation of macrophage foam cells (Halvorsen et al., 2005). The authors propose that IL-10 not only enhances foam cell formation but also has anti-apoptotic effects by increasing the expression of anti-apoptotic genes Bfl-1 and Mcl-1 (Halvorsen et al., 2005). In 2006, Rubic and Lorenz showed that IL-10 can stimulate ABCA1/ABCG1 which increases the cholesterol efflux from lipid-laden foam cells. In addition, they observed a down-regulation of CD36-mediated oxLDL uptake in macrophages. According to their results IL-10 is able to decrease oxLDL uptake and increase reverse cholesterol transport in macrophages, thereby preventing foam cell formation (Rubic and Lorenz, 2006). These results appear to contradict the report by Halvorsen et al. in which IL-10 increases foam cell formation. These confusing findings were partially clarified by a study by Han et al. in 2009 in which they reported that IL-10 modulates lipid metabolism in macrophages by facilitating both cholesterol uptake and efflux (Han et al., 2009). This study clearly revealed that IL-10 not only can up-regulate ABCA1 in a PPAR- $\gamma$-dependent mechanism but can increase the expression of scavenger receptors (scavenger receptor A and CD36). In support of this Montoya et al. reported that IL-10 stimulates the expression of scavenger receptors and enhances foam cell formation (Montoya et al., 2009). These data support the hypothesis that increased cholesterol uptake by IL-10 may be athero-protective by actively removing the highly atherogenic lipoproteins from the artery wall. On the other hand, the increase in ABCA1-dependent cholesterol efflux by IL-10 is a crucial factor in the efficient disposal of cytotoxic free cholesterol through reverse cholesterol transport. Interestingly, a recent report indicated that anti-inflammatory M2 macrophages but not pro-inflammatory M1 macrophages rapidly accumulate oxidized LDL (van Tits et al., 2011). As IL-10 is one of the effectors that promote M2 macrophage polarization as mentioned above (Martinez et al., 2009) (Tabas, 2010), it is likely that IL-10 is involved in the lipid accumulation predominantly in M2 macrophages. These results present a comprehensive anti-atherogenic role of IL-10 in macrophages, along with a more 
traditional role of IL-10 in inhibiting inflammatory molecules (e.g. TNF- $\alpha$, iCAM-1, and MMP9) and reducing apoptosis (Han et al., 2009) (Han et al., 2010) . A cartoon depicting the multi-faceted anti-atherogenic role of IL-10 in macrophages is shown in the figure below.

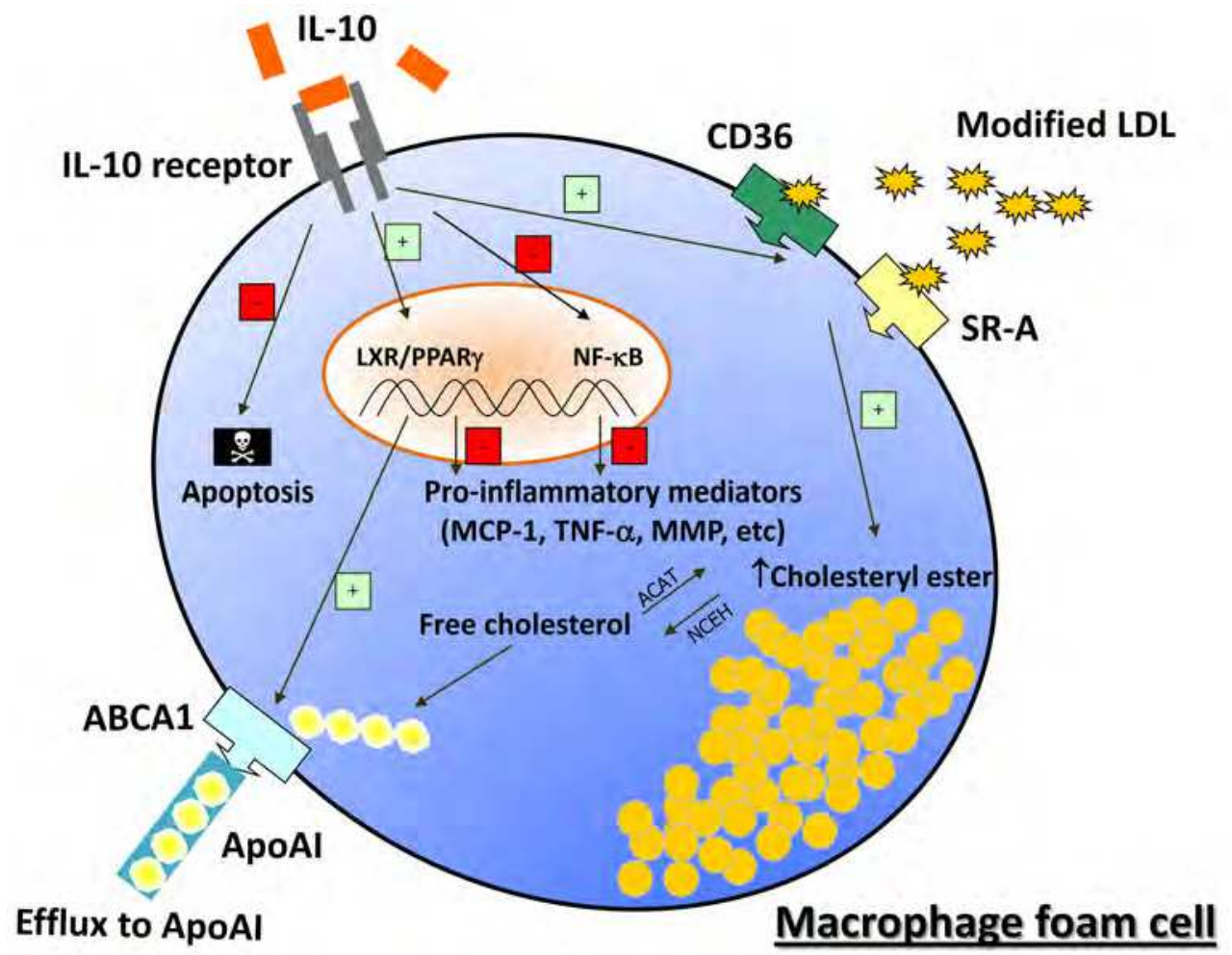

Fig. 1. Schematic overview of the protective role of IL-10 during atherosclerosis involving regulation of lipid metabolism in macrophages. Upon binding to its receptor, IL-10 upregulates scavenger receptors, SR-A (SR-I and SR-II) and CD36, which account for an increase in modified LDL uptake by macrophages. This promotes cholesteryl ester accumulation and foam cell formation. IL-10 also promotes ABCA1-mediated free cholesterol efflux to apoAI in a PPAR $\gamma$-dependent manner. In a more traditional role as an anti-inflammatory cytokine, IL-10 markedly suppresses the expression of pro-inflammatory molecules such as TNF- $\alpha$, MCP-1 and MMPs, presumably through the inhibition of NF- $\mathrm{B}$ activity as documented before (Wang et al., 1995), and diminishes apoptosis in the lipidladen foam cells (Han et al., 2009).

\subsection{Influence on T lymphocyte function}

Recent publications have shown that, although $\mathrm{T}$ cell numbers are far fewer than mononuclear phagocytes, they are also recruited to the intima and play an important role in the development of atherogenesis. Therefore, the protective action of IL-10 in atherogenesis is likely to involve $\mathrm{T}$ cell immune response. 


\subsubsection{Polarization and balance of $T$ helper cells}

$\mathrm{T}$ lymphocytes are found in lesions in an activated state and coexist with lesion macrophages, particularly in early phases of atherosclerosis. The key role for Th1 cytokines, such as IL-12 (Lee et al., 1999) or IFN- $\gamma$ (Gupta et al., 1997) as well as the general role of lesion T lymphocytes in atherogenesis have been reviewed elsewhere (Daugherty and Rateri, 2002). As a prototypic anti-inflammatory cytokine, IL-10 down-regulates Th1 cytokines such as IL-12 and IL-18 leading to inhibition of Th1-biased immune response (Moore et al., 2001), and polarization of the Th1:Th2 balances toward Th2 (Daugherty and Rateri, 2002). Induction of a regulatory T cell type 1 response attenuates the development of atherosclerosis in apoE-knockout mice by decreasing the Th1 response, decreasing the production of IFN- $\gamma$ and increasing IL-10 production (Mallat et al., 2003). Also, it may be that the reduction in atherosclerotic lesion formation in FcrRIII (CD16) -/- mice crossed onto the LDLR-/- mice is associated with increased production of IL-10 by the expansion of CD4+ T cells (Kelly et al., 2010).

The imbalance between pro- and anti-inflammatory forces influences plaque disruption and recurrent cardiovascular events (Trompet et al., 2007) with a shift towards the Th1 dominance seen in atherosclerosis patients (Ait-Oufella et al., 2011). In support of this concept is the report that serum IL-18/IL-10 ratio is an independent predictor of in-hospital adverse events in patients with acute coronary syndrome (Chalikias et al., 2005). Furthermore, an anti-inflammatory marker such as IL-10 is a better prognostic marker than inflammatory markers such as CRP and IL-18 to predict cardiovascular events in ACS patients (Tziakas et al., 2007). Likewise, it has been demonstrated that CRP accentuates inflammation, which is pivotal in atherothrombosis, by lowering IL-10, thereby altering the anti-inflammatory/pro-inflammatory balance (Singh et al., 2006). There is an inverse correlation between pro-inflammatory CRP and anti-inflammatory IL-10 levels in patients with athersoclerosis (Seyrek et al., 2005). More recently, an inflammatory imbalance between the TNF- $\alpha$ system and IL-10 has been characterized in children with familial hypercholesterolemia (Narverud et al., 2011).

Th1 biased phenotype is responsible for clinical instability (Liuzzo et al., 2000) and atherogenesis (Jonsson et al., 2001) (Hurt-Camejo et al., 2001) (Laurat et al., 2001) (Zhou et al., 1998) (Caligiuri et al., 2003) (Mallat and Tedgui, 2004) (Mallat et al., 2005). Interestingly, in IL-10-/- ApoE-/- double KO mice, Th1-bias was accompanied by a higher susceptibility to atherosclerosis, but only at the early stage of the disease when macrophages dominate (which is when they are sensitive to Th1 and Th2 cytokines (Caligiuri et al., 2003)).

\subsubsection{Regulatory $T$ cells and Th17 cells}

Recently, the role of regulatory T cells (Treg) and IL-17-producing T cells (Th17 cells) has been emphasized in atherosclerosis (Taleb et al., 2010) (Lahoute et al., 2011). Treg are important in protection against atherosclerosis at least in part through the production of IL10 (Mor et al., 2007) (Taleb et al., 2010) (George, 2008) (Feng et al., 2009). It is also believed that the pro-atherogenic response by Th1 cells can be controlled by Treg (Binder et al., 2004). IL-17-producing Th17 cells also play an important role in atherosclerosis (Hansson and Hermansson, 2011). Irradiated LDLR-/- mice transplanted with IL-17R deficient bone marrow exhibit reduced lesion size in aortic root, increased IL-10 production, and decreased IL-6 production (van Es et al., 2009). This suggests that signaling via the IL-17 receptor in bone marrow derived cells enhances atherosclerosis. Similarly, blockade of IL-17 results in reduced atherosclerosis in apoE-/- mice (Smith et al., 2010) (Erbel et al., 2009). However, the role of IL- 
17 in atherogenesis is controversial in that increased level of IL-17 is associated with a stable human plaque phenotype while defective Th17 cell differentiation may be implicated in increased susceptibility to vascular inflammation (Taleb et al., 2009). In addition, Th17 response is protective against vascular inflammation and the progression of atherosclerosis (Taleb et al., 2010). Similarly, a deficiency of SOCS3 in T cells leads to IL-17-dependent reduction in lesion development and vascular inflammation by increasing IL-17 and IL-10 production, and by inducing an anti-inflammatory macrophage phenotype (Taleb et al., 2009)

\section{Human studies and in vivo animal models}

The role of IL-10 in atherosclerosis has been investigated using different animal models as listed on the table below. In 1996, Uyemura et al. (Uyemura et al., 1996) first described that IL-10 was produced in human atherosclerotic lesions and that ox-LDL induced IL-10 release from monocytes in vitro. The down-regulation of IL-12 by IL-10 (Sieling et al., 1994) (D'Andrea et al., 1993) (de Waal Malefyt et al., 1991) observed in this study and others suggest that the balance between IL-12 and IL-10 production contributes to the level of immune-mediated tissue injury in atherosclerosis. IL-12 and IL-10 are two important cytokines produced by activated monocytes that regulate the Th1 and Th2 responses, respectively (D'Andrea et al., 1992) (Gately et al., 1991) (Germann et al., 1993) (Hsieh et al., 1993) (Seder et al., 1993) (Sieling et al., 1994) (de Waal Malefyt et al., 1991) (Barnes et al., 1992). IL-12 is a T cell growth factor (Gately et al., 1991) that is primarily produced by activated monocytes (D'Andrea et al., 1992) which selectively induces the Th1 cytokine pattern (Gately et al., 1991) (Germann et al., 1993) (Hsieh et al., 1993) (Seder et al., 1993) (Sieling et al., 1994). One important mechanism of IL-10 action is that it inhibits the local production of IL-12 which may potentiate the chronic inflammatory Th1 cell and macrophage responses leading to tissue injury in atherosclerosis (Uyemura et al., 1996). The complicated issue of athero-regulation by both IL-12 and IL-10 was further exhibited by an observation that IL-12 is expressed at an earlier stage of atherosclerosis than IL-10 in apoE-/- mice (Lee et al., 1999). This suggests that IL-12 and IL-10 may play an active role in regulating the immune response during the different phases of atherosclerosis.

In 1999, Mallat et al. reported the expression and potential effects of IL-10 in advanced human atherosclerotic plaques (Mallat et al., 1999b). Immunohistochemical staining from this study indicated that macrophages in advanced human atherosclerotic plaques are the main source of IL-10. The local anti-inflammatory response of IL-10 and its effect on protection from excessive cell death in the plaque was supported by the data that high levels of IL-10 expression were associated with low levels of iNOS expression and cell death.

Studies involving IL-10-deficient and IL-10-overexpressing mouse models on either apoE-/or LDLR -/- background have greatly advanced our understanding of the mechanism of IL10 function in atherogenesis. In 1999, two labs independently reported that IL-10 is protective in atherosclerosis (Mallat et al., 1999a; Pinderski Oslund et al., 1999). Since then, more than ten groups utilized different animal models and various IL-10 delivery systems in an attempt to understand how IL-10 affects atherosclerosis. The first report using the IL-10deficient mice fed an atherogenic diet showed an increased lipid accumulation, higher T-cell infiltration, abundant IFN- $\gamma$ expression, and decreased collagen content in the lesion compared with wild-type mice (Mallat et al., 1999a). Transfer of murine 


\begin{tabular}{|c|c|c|c|}
\hline Publication & Approach & Animal model & Underlying mechanism \\
\hline $\begin{array}{l}\text { Mallat et al. 1999, } \\
\text { Circ Res (Mallat et } \\
\text { al., 1999a) }\end{array}$ & $\begin{array}{l}\text { IL-10-encoding plasmid } \\
\text { transferred to muscle cells using } \\
\text { electrotransfer procedures }\end{array}$ & C57BL/ 6 mice & $\begin{array}{l}\text { Inhibit inflammation, plaque collagen } \\
\text { content and stability }\end{array}$ \\
\hline $\begin{array}{l}\text { Pinderski Oslund et } \\
\text { al. 1999, ATVB } \\
\text { (Pinderski Oslund et } \\
\text { al., 1999) }\end{array}$ & $\begin{array}{l}\text { Systemic overexpression of IL- } \\
10\end{array}$ & C57BL/6J mice & $\begin{array}{l}\text { Block monocyte adhesion to human aortic } \\
\text { endothelial cells }\end{array}$ \\
\hline $\begin{array}{l}\text { Von der Thusen et } \\
\text { al. 2001, FASEB J } \\
\text { (Von Der Thusen et } \\
\text { al., 2001) }\end{array}$ & $\begin{array}{l}\text { Systemic adenovirus-mediated } \\
\text { transfer of IL-10 }\end{array}$ & LDLR-/- mice & $\begin{array}{l}\text { Monocyte deactivation by inhibition of } \\
\text { TNF- } \alpha \text { and lowering of serum cholesterol } \\
\text { levels }\end{array}$ \\
\hline $\begin{array}{l}\text { Pinderski et al. 2002, } \\
\text { Circ Res (Pinderski } \\
\text { et al., 2002) }\end{array}$ & $\begin{array}{l}\text { Murine IL-10 transgene under } \\
\text { human IL- } 2 \text { promoter, bone } \\
\text { marrow transplantation } \\
\text { (overexpression of IL- } 10 \text { by } \mathrm{T} \\
\text { cells) }\end{array}$ & LDLR -/- mice & $\begin{array}{l}\text { Polarization to Th2 phenotype; lowered } \\
\text { activation of monocytes; decreased } \\
\text { apoptosis of macrophage foam cells } \\
\text { within lesion }\end{array}$ \\
\hline $\begin{array}{l}\text { Caligiuri G et al. } \\
\text { 2003, } \\
\text { Mol Med (Caligiuri } \\
\text { et al., 2003) }\end{array}$ & IL-10 deficiency & ApoE-/- mice & $\begin{array}{l}\text { Increased Th1 response; increased TF and } \\
\text { MMP activity; increase in LDL and } \\
\text { decrease in vLDL in IL-10-/-ApoE-/- mice }\end{array}$ \\
\hline $\begin{array}{l}\text { Namiki M et al } 2004 \\
\text { Atherosclerosis } \\
\text { (Namiki et al., 2004) }\end{array}$ & $\begin{array}{l}\text { Intramuscular gene transfer of } \\
\text { IL-10 cDNA }\end{array}$ & ApoE-/-mice & $\begin{array}{l}\text { Change in the Th1 response by inhibiting } \\
\text { IL- } 12 \text { and IFN- } \gamma \text { expression }\end{array}$ \\
\hline $\begin{array}{l}\text { Yoshioka et al. 2004, } \\
\text { Gene Ther } \\
\text { (Yoshioka et al., } \\
\text { 2004) }\end{array}$ & $\begin{array}{l}\text { Systemic delivery of adeno- } \\
\text { associated virus vector (tibial } \\
\text { muscle injection) }\end{array}$ & ApoE-/-mice & $\begin{array}{l}\text { Inhibition of inflammation and oxidative } \\
\text { stress }\end{array}$ \\
\hline $\begin{array}{l}\text { Liu et al. 2006, } \\
\text { Atherosclerosis (Liu } \\
\text { et al., 2006) }\end{array}$ & $\begin{array}{l}\text { Systemic delivery (tail vein } \\
\text { injection) }\end{array}$ & LDLR-/- mice & $\begin{array}{l}\text { Anti-inflammatory (MCP-1) and } \\
\text { cholesterol-lowering effects }\end{array}$ \\
\hline $\begin{array}{l}\text { Namiki et al. 2004, } \\
\text { Atherosclerosis } \\
\text { (Namiki et al., 2004) }\end{array}$ & $\begin{array}{l}\text { Transfer of murine IL-10 cDNA } \\
\text { plasmid to femoral muscle with } \\
\text { Hemagglutinin virus of Japan } \\
\text { (HVJ)-liposome }\end{array}$ & ApoE-/-mice & $\begin{array}{l}\text { Reduced macrophage infiltration and } \\
\text { altered Th1 response }\end{array}$ \\
\hline $\begin{array}{l}\text { Han X, et al. } \\
\text { 2010, FASEB J (Han } \\
\text { et al., 2010) }\end{array}$ & $\begin{array}{l}\text { Overexpression of IL- } 10 \text { by } \\
\text { macrophages, bone marrow } \\
\text { transplantation }\end{array}$ & LDLR-/-mice & $\begin{array}{l}\text { Inhibition of inflammation and apoptosis; } \\
\text { modulation of lipid metabolism in foam } \\
\text { cells (both lipid uptake and cholesterol } \\
\text { efflux) }\end{array}$ \\
\hline $\begin{array}{l}\text { Du L, et al. } \\
\text { 2011, Human Gen } \\
\text { Therapy (Du et al., } \\
\text { 2011) }\end{array}$ & $\begin{array}{l}\text { Expression of IL-10 in carotid } \\
\text { arteries achieved with helper- } \\
\text { dependent adenoviral vector }\end{array}$ & Rabbit & No athero-protective effect \\
\hline
\end{tabular}


IL-10 through in vivo intramuscular electrotransfers of pCor-IL-10 plasmid DNA achieved a $60 \%$ reduction in lesion size in IL-10-deficient mice. In agreement with these findings, Pinderski Oslund et al. observed that diet-induced atherosclerotic lesions were larger in IL-10 null mice than in control mice (Pinderski Oslund et al., 1999). In addition, they also observed that transgenic murine IL-10 expression which was selectively driven in T cells by human IL-2 promoter decreased atherosclerotic lesion formation (Pinderski Oslund et al., 1999).

In 2001, von der Thusen and colleagues reported that increased plasma concentrations of IL-10 as a result of adenoviral gene transfer in LDLR-/- mice led to reduction in atherosclerotic lesion size by inhibiting the production of TNF- $\alpha$ (Han et al., 2010; Von Der Thusen et al., 2001). The mechanism involves the inhibition of anti-inflammatory TNF- $\alpha$ production by IL-10 (Han et al., 2010; Von Der Thusen et al., 2001). At the same time, Pinderski et al. demonstrated that overexpression of IL-10 by activated T lymphocytes attenuated lesion formation by driving the shift to a Th2 phenotype with decreased IFN- $\gamma$ production (by peripheral blood lymphocytes, splenocytes, and circulating monocytes) (Pinderski et al., 2002). Alteration of macrophage function was exhibited by markedly decreased apoptosis in macrophage foam cells within the lesions of IL-10 transgenic mice (Pinderski et al., 2002).

The athero-protective results obtained with IL-10-deficient mice on the C57BL/6J background (Mallat et al., 1999a; Pinderski Oslund et al., 1999) were confirmed in IL-10 and apoE double knockout mice as demonstrated by Caligiuri et al. (Caligiuri et al., 2003). Several significant findings were revealed by this study: (1) Th-1 response and lesion size were dramatically increased in double knockout mice compared with apoE-/- controls at the early phase of lesion development; (2) the proteolytic and procoagulant activity was elevated in advanced lesions as indicated by an increase in TF and MMP activities, suggesting that IL-10 may reduce atherogenesis and improve the stability of plaques; and (3) lipid metabolism regulated by IL-10 was implicated in this study as LDL cholesterol was increased but VLDL was decreased in the double KO mice without significant changes in total cholesterol or triglyceride levels (Caligiuri et al., 2003).

In an attempt to utilize IL-10 as a therapeutic agent, several techniques have been used by different groups to deliver the IL-10 gene in vivo. One study showed that intramuscular gene transfer of IL-10 cDNA reduces atherosclerotic lesion formation in apoE-/- mice (Namiki et al., 2004). IL-10 gene transfer quelled the Th1 response by inhibiting IL-12 and IFN- $\gamma$ expression in transgenic mice (Namiki et al., 2004). These results were confirmed in another study in which adeno-associated virus vector-mediated IL-10 gene transfer via intramuscular injection inhibited atherosclerosis in apoE-/- mice (Yoshioka et al., 2004) by lowering MCP-1 expression in both the vascular wall of the ascending aorta and serum. In agreement with these results, a systemic delivery of adeno-associated virus type 2-hIL-10 inhibited atherogenesis in LDLR-/- mice by combating inflammation and oxidative stress (Liu et al., 2006). Similar effects of IL-10 deficiency and overexpression on neointima formation were seen in the hypercholesterolemic apoE*3-Leiden mice as well (Eefting et al., 2007).

Anti-atherosclerotic properties of IL-10 were further displayed in high fat diet-fed LDLR -/mice in which IL-10 was overexpressed in macrophages by utilizing a macrophage-specific retroviral vector that allows long-term in vivo expression of IL-10 in macrophages through transplantation of retrovirally transduced bone marrow cells (BMCs) (Han et al., 2010). The 
IL-10 expressed by macrophages in the plaques derived from transduced BMCs inhibited atherosclerosis in these mice, at least in part by reducing the inflammation and apoptosis in IL-10-overexpressing macrophages. These results are consistent with previous findings (Han et al., 2009) and provided evidence that IL-10 production in macrophages is protective against atherosclerosis. Their results also highlight a novel therapeutic technique against atherosclerosis using an effective stem cell transduction system that allows prolonged production of IL-10 from macrophages.

It is worth emphasizing that most strategies mentioned above had systemic effects on multiple cells including $\mathrm{T}$ cells, monocytes and endothelium resulting from overexpression of IL-10 in circulation. For example, overexpression of IL-10 in activated T lymphocytes inhibited monocyte activation and led to a shift to either Th2 phenotype (Pinderski et al., 2002) or Th1 phenotype (Zhou et al., 1998). As a cytokine with diverse effects on most hematopoietic cell types, IL-10 can inhibit the activation and effector function of T cells, monocytes, and macrophages (Moore et al., 2001). In addition, IL-10 can regulate the growth and/or differentiation of B cells, NK cells, cytotoxic and helper T cells, mast cells, granulocytes, dendritic cells, keratinocytes, and endothelial cells (Moore et al., 2001). Therefore, alterations in circulating IL-10 levels can influence the function of other immune cells which may in turn influence atherosclerosis. In the study by Han et al. there was no detectable IL-10 in circulating plasma at any time point during the atherogenic diet feeding whereas IL-10 was readily detected in IL-10-overexpressing macrophages in atherosclerotic lesions. This suggests that IL-10 was expressed in differentiated macrophages but not in circulating monocytes. Therefore, their technique of overexpressing IL-10 only in differentiated macrophages is useful to evaluate the unique role of locally-produced IL-10 in atherogenesis, and clearly shows that IL-10 acting in the vessel wall can decrease the development of atherosclerosis despite ongoing hyperlipidemia.

However, a recent study using a rabbit model showed that prolonged and stable expression of IL-10 in rabbit carotid arteries achieved with a helper-dependent adenoviral vector had neither an atheroprotective effect nor any effect on adhesion molecules or any other atherogenic cytokines (Du et al., 2011). Possible explanation accounting for the discrepant results may be inadequate protein expression in vivo or lack of suitability of this rabbit model to detect IL-10's therapeutic effects. This study suggests that gene therapy involving IL-10 delivery may bring about different results in different species.

\section{Therapeutic considerations}

In light of the findings that systemic and intralesional delivery of IL-10 can be antiatherogenic, it is tempting to speculate that IL-10 treatment may have the potential to be a novel therapeutic agent against atherosclerosis in the future. IL-10 expression after intramuscular DNA electrotransfer or other techniques leads to a persistent expression of this protective cytokine in circulation and in local lesion (Deleuze et al., 2002; Han et al., 2010; Pinderski et al., 2002). It is likely that systemic delivery of IL-10 will result in suppression of immune response and increase the opportunity of infection, particularly involving intracellular pathogens such as Chlamydia and Listeria monocytogenes (Terkeltaub, 1999). Compared with systemic delivery of IL-10, local expression of IL-10 in atherosclerotic lesions may have much less impact on the general immune response. On the other hand, a robust local expression driven by retrovirus or adenovirus makes it difficult to regulate IL10 expression in a temporally and spatially controllable manner as desired. Accordingly, the 
safety and effectiveness of exogenous IL-10 administration utilizing these techniques will need to be evaluated in the future before they are adopted in human patients for the treatment of atherosclerosis.

\section{References}

Ait-Oufella, H., Taleb, S., Mallat, Z., and Tedgui, A. (2011). Recent advances on the role of cytokines in atherosclerosis. Arterioscler Thromb Vasc Biol 31, 969-979.

Ajuebor, M.N., Das, A.M., Virag, L., Flower, R.J., Szabo, C., and Perretti, M. (1999). Role of resident peritoneal macrophages and mast cells in chemokine production and neutrophil migration in acute inflammation: evidence for an inhibitory loop involving endogenous IL-10. J Immunol 162, 1685-1691.

Albina, J.E., Cui, S., Mateo, R.B., and Reichner, J.S. (1993). Nitric oxide-mediated apoptosis in murine peritoneal macrophages. J Immunol 150, 5080-5085.

Amento, E.P., Ehsani, N., Palmer, H., and Libby, P. (1991). Cytokines and growth factors positively and negatively regulate interstitial collagen gene expression in human vascular smooth muscle cells. Arterioscler Thromb 11, 1223-1230.

Arai, T., Hiromatsu, K., Nishimura, H., Kimura, Y., Kobayashi, N., Ishida, H., Nimura, Y., and Yoshikai, Y. (1995). Endogenous interleukin 10 prevents apoptosis in macrophages during Salmonella infection. Biochem Biophys Res Commun 213, 600607.

Ardissino, D., Merlini, P.A., Ariens, R., Coppola, R., Bramucci, E., and Mannucci, P.M. (1997). Tissue-factor antigen and activity in human coronary atherosclerotic plaques. Lancet 349, 769-771.

Arnman, V., Stemme, S., Rymo, L., and Risberg, B. (1995). Interferon-gamma modulates the fibrinolytic response in cultured human endothelial cells. Thromb Res 77, 431-440.

Barnes, P.F., Chatterjee, D., Abrams, J.S., Lu, S., Wang, E., Yamamura, M., Brennan, P.J., and Modlin, R.L. (1992). Cytokine production induced by Mycobacterium tuberculosis lipoarabinomannan. Relationship to chemical structure. J Immunol 149, 541-547.

Beaven, S.W., and Tontonoz, P. (2006). Nuclear receptors in lipid metabolism: targeting the heart of dyslipidemia. Annu Rev Med 57, 313-329.

Benoit, M., Desnues, B., and Mege, J.L. (2008). Macrophage polarization in bacterial infections. J Immunol 181, 3733-3739.

Biasucci, L.M., Liuzzo, G., Caligiuri, G., Quaranta, G., Andreotti, F., Sperti, G., van de Greef, W., Rebuzzi, A.G., Kluft, C., and Maseri, A. (1996). Temporal relation between ischemic episodes and activation of the coagulation system in unstable angina. Circulation 93, 2121-2127.

Binder, C.J., Hartvigsen, K., Chang, M.K., Miller, M., Broide, D., Palinski, W., Curtiss, L.K., Corr, M., and Witztum, J.L. (2004). IL-5 links adaptive and natural immunity specific for epitopes of oxidized LDL and protects from atherosclerosis. J Clin Invest 114, 427-437.

Bjorkerud, S., and Bjorkerud, B. (1996). Apoptosis is abundant in human atherosclerotic lesions, especially in inflammatory cells (macrophages and T cells), and may contribute to the accumulation of gruel and plaque instability. Am J Pathol 149, 367-380.

Bobik, A., Agrotis, A., Kanellakis, P., Dilley, R., Krushinsky, A., Smirnov, V., Tararak, E., Condron, M., and Kostolias, G. (1999). Distinct patterns of transforming growth 
factor-beta isoform and receptor expression in human atherosclerotic lesions. Colocalization implicates TGF-beta in fibrofatty lesion development. Circulation 99, 2883-2891.

Bogdan, C., Vodovotz, Y., and Nathan, C. (1991). Macrophage deactivation by interleukin 10. J Exp Med 174, 1549-1555.

Boisvert, W.A., Santiago, R., Curtiss, L.K., and Terkeltaub, R.A. (1998). A leukocyte homologue of the IL-8 receptor CXCR-2 mediates the accumulation of macrophages in atherosclerotic lesions of LDL receptor-deficient mice. J Clin Invest 101, 353-363.

Bouhlel, M.A., Derudas, B., Rigamonti, E., Dievart, R., Brozek, J., Haulon, S., Zawadzki, C., Jude, B., Torpier, G., Marx, N., et al. (2007). PPARgamma activation primes human monocytes into alternative M2 macrophages with anti-inflammatory properties. Cell Metab 6, 137-143.

Boyle, J.J. (2005). Macrophage activation in atherosclerosis: pathogenesis and pharmacology of plaque rupture. Curr Vasc Pharmacol 3, 63-68.

Brown, M.S., and Goldstein, J.L. (1983). Lipoprotein metabolism in the macrophage: implications for cholesterol deposition in atherosclerosis. Annu Rev Biochem 52, 223-261.

Brown, M.S., and Goldstein, J.L. (1997). The SREBP pathway: regulation of cholesterol metabolism by proteolysis of a membrane-bound transcription factor. Cell 89, 331340 .

Cai, W., Devaux, B., Schaper, W., and Schaper, J. (1997). The role of Fas/APO 1 and apoptosis in the development of human atherosclerotic lesions. Atherosclerosis 131, 177-186.

Caligiuri, G., Rudling, M., Ollivier, V., Jacob, M.P., Michel, J.B., Hansson, G.K., and Nicoletti, A. (2003). Interleukin-10 deficiency increases atherosclerosis, thrombosis, and lowdensity lipoproteins in apolipoprotein E knockout mice. Mol Med 9, 10-17.

Calkin, A.C., and Tontonoz, P. (2010). Liver $x$ receptor signaling pathways and atherosclerosis. Arterioscler Thromb Vasc Biol 30, 1513-1518.

Cattaruzza, M., Slodowski, W., Stojakovic, M., Krzesz, R., and Hecker, M. (2003). Interleukin-10 induction of nitric-oxide synthase expression attenuates CD40mediated interleukin-12 synthesis in human endothelial cells. J Biol Chem 278, 37874-37880.

Chalikias, G.K., Tziakas, D.N., Kaski, J.C., Hatzinikolaou, E.I., Stakos, D.A., Tentes, I.K., Kortsaris, A., and Hatseras, D.I. (2005). Interleukin-18: interleukin-10 ratio and inhospital adverse events in patients with acute coronary syndrome. Atherosclerosis 182, 135-143.

Charo, I.F. (2007). Macrophage polarization and insulin resistance: PPARgamma in control. Cell Metab 6, 96-98.

Charo, I.F., and Taub, R. (2011). Anti-inflammatory therapeutics for the treatment of atherosclerosis. Nat Rev Drug Discov 10, 365-376.

Chinetti-Gbaguidi, G., and Staels, B. Macrophage polarization in metabolic disorders: functions and regulation. Curr Opin Lipidol.

Chinetti, G., Lestavel, S., Bocher, V., Remaley, A.T., Neve, B., Torra, I.P., Teissier, E., Minnich, A., Jaye, M., Duverger, N., et al. (2001). PPAR-alpha and PPAR-gamma activators induce cholesterol removal from human macrophage foam cells through stimulation of the ABCA1 pathway. Nat Med 7, 53-58. 
Cohen, S.B., Crawley, J.B., Kahan, M.C., Feldmann, M., and Foxwell, B.M. (1997). Interleukin-10 rescues $\mathrm{T}$ cells from apoptotic cell death: association with an upregulation of Bcl-2. Immunology 92, 1-5.

D'Andrea, A., Aste-Amezaga, M., Valiante, N.M., Ma, X., Kubin, M., and Trinchieri, G. (1993). Interleukin 10 (IL-10) inhibits human lymphocyte interferon gammaproduction by suppressing natural killer cell stimulatory factor/IL-12 synthesis in accessory cells. J Exp Med 178, 1041-1048.

D'Andrea, A., Rengaraju, M., Valiante, N.M., Chehimi, J., Kubin, M., Aste, M., Chan, S.H., Kobayashi, M., Young, D., Nickbarg, E., et al. (1992). Production of natural killer cell stimulatory factor (interleukin 12) by peripheral blood mononuclear cells. J Exp Med 176, 1387-1398.

Daugherty, A., and Rateri, D.L. (2002). T lymphocytes in atherosclerosis: the yin-yang of Th1 and Th2 influence on lesion formation. Circ Res 90, 1039-1040.

de Vries, J.E. (1995). Immunosuppressive and anti-inflammatory properties of interleukin 10. Ann Med 27, 537-541.

de Waal Malefyt, R., Abrams, J., Bennett, B., Figdor, C.G., and de Vries, J.E. (1991). Interleukin 10(IL-10) inhibits cytokine synthesis by human monocytes: an autoregulatory role of IL-10 produced by monocytes. J Exp Med 174, 1209-1220.

Deleuze, V., Scherman, D., and Bureau, M.F. (2002). Interleukin-10 expression after intramuscular DNA electrotransfer: kinetic studies. Biochem Biophys Res Commun 299, 29-34.

Du, L., Dronadula, N., Tanaka, S., and Dichek, D.A. (2011). Helper-Dependent Adenoviral Vector Achieves Prolonged, Stable Expression of Interleukin-10 in Rabbit Carotid Arteries but Does Not Limit Early Atherogenesis. Hum Gene Ther.

Eefting, D., Schepers, A., De Vries, M.R., Pires, N.M., Grimbergen, J.M., Lagerweij, T., Nagelkerken, L.M., Monraats, P.S., Jukema, J.W., van Bockel, J.H., et al. (2007). The effect of interleukin-10 knock-out and overexpression on neointima formation in hypercholesterolemic APOE*3-Leiden mice. Atherosclerosis 193, 335-342.

Erbel, C., Chen, L., Bea, F., Wangler, S., Celik, S., Lasitschka, F., Wang, Y., Bockler, D., Katus, H.A., and Dengler, T.J. (2009). Inhibition of IL-17A attenuates atherosclerotic lesion development in apoE-deficient mice. J Immunol 183, 8167-8175.

Fei, G.Z., Huang, Y.H., Swedenborg, J., and Frostegard, J. (2003). Oxidised LDL modulates immune-activation by an IL-12 dependent mechanism. Atherosclerosis 169, 77-85.

Feng, J., Zhang, Z., Kong, W., Liu, B., Xu, Q., and Wang, X. (2009). Regulatory T cells ameliorate hyperhomocysteinaemia-accelerated atherosclerosis in apoE-/- mice. Cardiovasc Res 84, 155-163.

Ferri, L.A., Maugeri, N., Rovere-Querini, P., Calabrese, A., Ammirati, E., Cianflone, D., Maseri, A., and Manfredi, A.A. (2009). Anti-inflammatory action of apoptotic cells in patients with acute coronary syndromes. Atherosclerosis 205, 391-395.

Fitzgerald, M.L., Mujawar, Z., and Tamehiro, N. (2010). ABC transporters, atherosclerosis and inflammation. Atherosclerosis 211, 361-370.

Galkina, E., and Ley, K. (2009). Immune and inflammatory mechanisms of atherosclerosis $\left(^{*}\right)$. Annu Rev Immunol 27, 165-197.

Gallicchio, M., Hufnagl, P., Wojta, J., and Tipping, P. (1996). IFN-gamma inhibits thrombinand endotoxin-induced plasminogen activator inhibitor type 1 in human endothelial cells. J Immunol 157, 2610-2617. 
Gately, M.K., Desai, B.B., Wolitzky, A.G., Quinn, P.M., Dwyer, C.M., Podlaski, F.J., Familletti, P.C., Sinigaglia, F., Chizonnite, R., Gubler, U., et al. (1991). Regulation of human lymphocyte proliferation by a heterodimeric cytokine, IL-12 (cytotoxic lymphocyte maturation factor). J Immunol 147, 874-882.

Geng, Y.J., and Libby, P. (1995). Evidence for apoptosis in advanced human atheroma. Colocalization with interleukin-1 beta-converting enzyme. Am J Pathol 147, 251266.

Geng, Y.J., Wu, Q., Muszynski, M., Hansson, G.K., and Libby, P. (1996). Apoptosis of vascular smooth muscle cells induced by in vitro stimulation with interferongamma, tumor necrosis factor-alpha, and interleukin-1 beta. Arterioscler Thromb Vasc Biol 16, 19-27.

George, J. (2008). Mechanisms of disease: the evolving role of regulatory $\mathrm{T}$ cells in atherosclerosis. Nat Clin Pract Cardiovasc Med 5, 531-540.

Gerard, C., Bruyns, C., Marchant, A., Abramowicz, D., Vandenabeele, P., Delvaux, A., Fiers, W., Goldman, M., and Velu, T. (1993). Interleukin 10 reduces the release of tumor necrosis factor and prevents lethality in experimental endotoxemia. J Exp Med 177, 547-550.

Germann, T., Gately, M.K., Schoenhaut, D.S., Lohoff, M., Mattner, F., Fischer, S., Jin, S.C., Schmitt, E., and Rude, E. (1993). Interleukin-12/T cell stimulating factor, a cytokine with multiple effects on T helper type 1 (Th1) but not on Th2 cells. Eur J Immunol 23, 1762-1770.

Gosling, J., Slaymaker, S., Gu, L., Tseng, S., Zlot, C.H., Young, S.G., Rollins, B.J., and Charo, I.F. (1999). MCP-1 deficiency reduces susceptibility to atherosclerosis in mice that overexpress human apolipoprotein B. J Clin Invest 103, 773-778.

Gough, P.J., Gomez, I.G., Wille, P.T., and Raines, E.W. (2006). Macrophage expression of active MMP-9 induces acute plaque disruption in apoE-deficient mice. J Clin Invest 116, 59-69.

Gupta, S., Pablo, A.M., Jiang, X., Wang, N., Tall, A.R., and Schindler, C. (1997). IFN-gamma potentiates atherosclerosis in ApoE knock-out mice. J Clin Invest 99, 2752-2761.

Halvorsen, B., Waehre, T., Scholz, H., Clausen, O.P., von der Thusen, J.H., Muller, F., Heimli, H., Tonstad, S., Hall, C., Froland, S.S., et al. (2005). Interleukin-10 enhances the oxidized LDL-induced foam cell formation of macrophages by antiapoptotic mechanisms. J Lipid Res 46, 211-219.

Han, D.K., Haudenschild, C.C., Hong, M.K., Tinkle, B.T., Leon, M.B., and Liau, G. (1995). Evidence for apoptosis in human atherogenesis and in a rat vascular injury model. Am J Pathol 147, 267-277.

Han, X., Kitamoto, S., Lian, Q., and Boisvert, W.A. (2009). Interleukin-10 facilitates both cholesterol uptake and efflux in macrophages. J Biol Chem 284, 32950-32958.

Han, X., Kitamoto, S., Wang, H., and Boisvert, W.A. (2010). Interleukin-10 overexpression in macrophages suppresses atherosclerosis in hyperlipidemic mice. FASEB J 24, 28692880.

Hansson, G.K. (2001). Immune mechanisms in atherosclerosis. Arterioscler Thromb Vasc Biol 21, 1876-1890.

Hansson, G.K., and Hermansson, A. (2011). The immune system in atherosclerosis. Nat Immunol 12, 204-212. 
Hansson, G.K., and Libby, P. (2006). The immune response in atherosclerosis: a doubleedged sword. Nat Rev Immunol 6, 508-519.

Hansson, G.K., Libby, P., Schonbeck, U., and Yan, Z.Q. (2002). Innate and adaptive immunity in the pathogenesis of atherosclerosis. Circ Res 91, 281-291.

Hansson, G.K., Robertson, A.K., and Soderberg-Naucler, C. (2006). Inflammation and atherosclerosis. Annu Rev Pathol 1, 297-329.

Heeschen, C., Dimmeler, S., Hamm, C.W., Fichtlscherer, S., Boersma, E., Simoons, M.L., and Zeiher, A.M. (2003). Serum level of the antiinflammatory cytokine interleukin-10 is an important prognostic determinant in patients with acute coronary syndromes. Circulation 107, 2109-2114.

Holven, K.B., Halvorsen, B., Bjerkeli, V., Damas, J.K., Retterstol, K., Morkrid, L., Ose, L., Aukrust, P., and Nenseter, M.S. (2006). Impaired inhibitory effect of interleukin-10 on the balance between matrix metalloproteinase- 9 and its inhibitor in mononuclear cells from hyperhomocysteinemic subjects. Stroke 37, 1731-1736.

Hsieh, C.S., Macatonia, S.E., Tripp, C.S., Wolf, S.F., O'Garra, A., and Murphy, K.M. (1993). Development of TH1 CD4+ T cells through IL-12 produced by Listeria-induced macrophages. Science 260, 547-549.

Hurt-Camejo, E., Paredes, S., Masana, L., Camejo, G., Sartipy, P., Rosengren, B., Pedreno, J., Vallve, J.C., Benito, P., and Wiklund, O. (2001). Elevated levels of small, lowdensity lipoprotein with high affinity for arterial matrix components in patients with rheumatoid arthritis: possible contribution of phospholipase A2 to this atherogenic profile. Arthritis Rheum 44, 2761-2767.

Isner, J.M., Kearney, M., Bortman, S., and Passeri, J. (1995). Apoptosis in human atherosclerosis and restenosis. Circulation 91, 2703-2711.

Ito, T., and Ikeda, U. (2003). Inflammatory cytokines and cardiovascular disease. Curr Drug Targets Inflamm Allergy 2, 257-265.

Jonsson, S.W., Backman, C., Johnson, O., Karp, K., Lundstrom, E., Sundqvist, K.G., and Dahlqvist, S.R. (2001). Increased prevalence of atherosclerosis in patients with medium term rheumatoid arthritis. J Rheumatol 28, 2597-2602.

Kai, H., Ikeda, H., Yasukawa, H., Kai, M., Seki, Y., Kuwahara, F., Ueno, T., Sugi, K., and Imaizumi, T. (1998). Peripheral blood levels of matrix metalloproteases-2 and -9 are elevated in patients with acute coronary syndromes. J Am Coll Cardiol 32, 368-372.

Kamimura, M., Viedt, C., Dalpke, A., Rosenfeld, M.E., Mackman, N., Cohen, D.M., Blessing, E., Preusch, M., Weber, C.M., Kreuzer, J., et al. (2005). Interleukin-10 suppresses tissue factor expression in lipopolysaccharide-stimulated macrophages via inhibition of Egr-1 and a serum response element/MEK-ERK1/2 pathway. Circ Res 97, 305-313.

Kelly, J.A., Griffin, M.E., Fava, R.A., Wood, S.G., Bessette, K.A., Miller, E.R., Huber, S.A., Binder, C.J., Witztum, J.L., and Morganelli, P.M. (2010). Inhibition of arterial lesion progression in CD16-deficient mice: evidence for altered immunity and the role of IL-10. Cardiovasc Res 85, 224-231.

Kennedy, M.A., Barrera, G.C., Nakamura, K., Baldan, A., Tarr, P., Fishbein, M.C., Frank, J., Francone, O.L., and Edwards, P.A. (2005). ABCG1 has a critical role in mediating cholesterol efflux to HDL and preventing cellular lipid accumulation. Cell Metab 1, 121-131. 
Khallou-Laschet, J., Varthaman, A., Fornasa, G., Compain, C., Gaston, A.T., Clement, M., Dussiot, M., Levillain, O., Graff-Dubois, S., Nicoletti, A., et al. Macrophage plasticity in experimental atherosclerosis. PLoS One 5, e8852.

Kishore, R., Tebo, J.M., Kolosov, M., and Hamilton, T.A. (1999). Cutting edge: clustered AUrich elements are the target of IL-10-mediated mRNA destabilization in mouse macrophages. J Immunol 162, 2457-2461.

Kleemann, R., Zadelaar, S., and Kooistra, T. (2008). Cytokines and atherosclerosis: a comprehensive review of studies in mice. Cardiovasc Res 79, 360-376.

Kockx, M.M., Muhring, J., Knaapen, M.W., and de Meyer, G.R. (1998). RNA synthesis and splicing interferes with DNA in situ end labeling techniques used to detect apoptosis. Am J Pathol 152, 885-888.

Lahoute, C., Herbin, O., Mallat, Z., and Tedgui, A. (2011). Adaptive immunity in atherosclerosis: mechanisms and future therapeutic targets. Nat Rev Cardiol 8, 348358.

Laurat, E., Poirier, B., Tupin, E., Caligiuri, G., Hansson, G.K., Bariety, J., and Nicoletti, A. (2001). In vivo downregulation of $\mathrm{T}$ helper cell 1 immune responses reduces atherogenesis in apolipoprotein E-knockout mice. Circulation 104, 197-202.

Lee, T.S., Yen, H.C., Pan, C.C., and Chau, L.Y. (1999). The role of interleukin 12 in the development of atherosclerosis in ApoE-deficient mice. Arterioscler Thromb Vasc Biol 19, 734-742.

Li, Y., Zhang, Y., Dorweiler, B., Cui, D., Wang, T., Woo, C.W., Brunkan, C.S., Wolberger, C., Imai, S., and Tabas, I. (2008). Extracellular Nampt promotes macrophage survival via a nonenzymatic interleukin-6/STAT3 signaling mechanism. J Biol Chem 283, 34833-34843.

Liao, H.S., Kodama, T., and Geng, Y.J. (2000). Expression of class A scavenger receptor inhibits apoptosis of macrophages triggered by oxidized low density lipoprotein and oxysterol. Arterioscler Thromb Vasc Biol 20, 1968-1975.

Libby, P. (1995). Molecular bases of the acute coronary syndromes. Circulation 91, 28442850.

Libby, P., Ridker, P.M., and Hansson, G.K. (2011). Progress and challenges in translating the biology of atherosclerosis. Nature 473, 317-325.

Little, P.J., Chait, A., and Bobik, A. (2011). Cellular and cytokine-based inflammatory processes as novel therapeutic targets for the prevention and treatment of atherosclerosis. Pharmacol Ther 131, 255-268.

Liu, Y., Li, D., Chen, J., Xie, J., Bandyopadhyay, S., Zhang, D., Nemarkommula, A.R., Liu, H., Mehta, J.L., and Hermonat, P.L. (2006). Inhibition of atherogenesis in LDLR knockout mice by systemic delivery of adeno-associated virus type 2-hIL-10. Atherosclerosis 188, 19-27.

Liuzzo, G., Goronzy, J.J., Yang, H., Kopecky, S.L., Holmes, D.R., Frye, R.L., and Weyand, C.M. (2000). Monoclonal T-cell proliferation and plaque instability in acute coronary syndromes. Circulation 101, 2883-2888.

Luoma, J.S., Stralin, P., Marklund, S.L., Hiltunen, T.P., Sarkioja, T., and Yla-Herttuala, S. (1998). Expression of extracellular SOD and iNOS in macrophages and smooth muscle cells in human and rabbit atherosclerotic lesions: colocalization with epitopes characteristic of oxidized LDL and peroxynitrite-modified proteins. Arterioscler Thromb Vasc Biol 18, 157-167. 
Lusis, A.J. (2000). Atherosclerosis. Nature 407, 233-241.

Mallat, Z., Ait-Oufella, H., and Tedgui, A. (2005). Regulatory T cell responses: potential role in the control of atherosclerosis. Curr Opin Lipidol 16, 518-524.

Mallat, Z., Besnard, S., Duriez, M., Deleuze, V., Emmanuel, F., Bureau, M.F., Soubrier, F., Esposito, B., Duez, H., Fievet, C., et al. (1999a). Protective role of interleukin-10 in atherosclerosis. Circ Res 85, e17-24.

Mallat, Z., Gojova, A., Brun, V., Esposito, B., Fournier, N., Cottrez, F., Tedgui, A., and Groux, H. (2003). Induction of a regulatory $T$ cell type 1 response reduces the development of atherosclerosis in apolipoprotein E-knockout mice. Circulation 108, $1232-1237$.

Mallat, Z., Heymes, C., Ohan, J., Faggin, E., Leseche, G., and Tedgui, A. (1999b). Expression of interleukin-10 in advanced human atherosclerotic plaques: relation to inducible nitric oxide synthase expression and cell death. Arterioscler Thromb Vasc Biol 19, 611-616.

Mallat, Z., and Tedgui, A. (2004). Immunomodulation to combat atherosclerosis: the potential role of immune regulatory cells. Expert Opin Biol Ther 4, 1387-1393.

Mantovani, A., Sica, A., and Locati, M. (2005). Macrophage polarization comes of age. Immunity 23, 344-346.

Marleau, S., Harb, D., Bujold, K., Avallone, R., Iken, K., Wang, Y., Demers, A., Sirois, M.G., Febbraio, M., Silverstein, R.L., et al. (2005). EP 80317, a ligand of the CD36 scavenger receptor, protects apolipoprotein E-deficient mice from developing atherosclerotic lesions. FASEB J 19, 1869-1871.

Martinez, F.O., Helming, L., and Gordon, S. (2009). Alternative activation of macrophages: an immunologic functional perspective. Annu Rev Immunol 27, 451-483.

Martinez, F.O., Sica, A., Mantovani, A., and Locati, M. (2008). Macrophage activation and polarization. Front Biosci 13, 453-461.

Maskrey, B.H., Megson, I.L., Whitfield, P.D., and Rossi, A.G. (2011). Mechanisms of resolution of inflammation: a focus on cardiovascular disease. Arterioscler Thromb Vasc Biol 31, 1001-1006.

Minor, R.L., Jr., Myers, P.R., Guerra, R., Jr., Bates, J.N., and Harrison, D.G. (1990). Dietinduced atherosclerosis increases the release of nitrogen oxides from rabbit aorta. J Clin Invest 86, 2109-2116.

Montoya, D., Cruz, D., Teles, R.M., Lee, D.J., Ochoa, M.T., Krutzik, S.R., Chun, R., Schenk, M., Zhang, X., Ferguson, B.G., et al. (2009). Divergence of macrophage phagocytic and antimicrobial programs in leprosy. Cell Host Microbe 6, 343-353.

Moore, K.J., Kunjathoor, V.V., Koehn, S.L., Manning, J.J., Tseng, A.A., Silver, J.M., McKee, M., and Freeman, M.W. (2005). Loss of receptor-mediated lipid uptake via scavenger receptor A or CD36 pathways does not ameliorate atherosclerosis in hyperlipidemic mice. J Clin Invest 115, 2192-2201.

Moore, K.J., and Tabas, I. (2011). Macrophages in the pathogenesis of atherosclerosis. Cell 145, 341-355.

Moore, K.W., de Waal Malefyt, R., Coffman, R.L., and O'Garra, A. (2001). Interleukin-10 and the interleukin-10 receptor. Annu Rev Immunol 19, 683-765.

Mor, A., Planer, D., Luboshits, G., Afek, A., Metzger, S., Chajek-Shaul, T., Keren, G., and George, J. (2007). Role of naturally occurring CD4+ CD25+ regulatory T cells in experimental atherosclerosis. Arterioscler Thromb Vasc Biol 27, 893-900. 
Moubayed, S.P., Heinonen, T.M., and Tardif, J.C. (2007). Anti-inflammatory drugs and atherosclerosis. Curr Opin Lipidol 18, 638-644.

Nagy, L., Tontonoz, P., Alvarez, J.G., Chen, H., and Evans, R.M. (1998). Oxidized LDL regulates macrophage gene expression through ligand activation of PPARgamma. Cell 93, 229-240.

Namiki, M., Kawashima, S., Yamashita, T., Ozaki, M., Sakoda, T., Inoue, N., Hirata, K., Morishita, R., Kaneda, Y., and Yokoyama, M. (2004). Intramuscular gene transfer of interleukin-10 cDNA reduces atherosclerosis in apolipoprotein E-knockout mice. Atherosclerosis 172, 21-29.

Narverud, I., Ueland, T., Nenseter, M.S., Retterstol, K., Telle-Hansen, V.H., Halvorsen, B., Ose, L., Aukrust, P., and Holven, K.B. (2011). Children with familial hypercholesterolemia are characterized by an inflammatory imbalance between the tumor necrosis factor alpha system and interleukin-10. Atherosclerosis 214, 163-168.

Nishihira, K., Imamura, T., Yamashita, A., Hatakeyama, K., Shibata, Y., Nagatomo, Y., Date, H., Kita, T., Eto, T., and Asada, Y. (2006). Increased expression of interleukin-10 in unstable plaque obtained by directional coronary atherectomy. Eur Heart J 27, 1685-1689.

Noel, W., Raes, G., Hassanzadeh Ghassabeh, G., De Baetselier, P., and Beschin, A. (2004). Alternatively activated macrophages during parasite infections. Trends Parasitol 20, 126-133.

Pajkrt, D., van der Poll, T., Levi, M., Cutler, D.L., Affrime, M.B., van den Ende, A., ten Cate, J.W., and van Deventer, S.J. (1997). Interleukin-10 inhibits activation of coagulation and fibrinolysis during human endotoxemia. Blood 89, 2701-2705.

Pasqui, A.L., Di Renzo, M., Bova, G., Maffei, S., Pompella, G., Auteri, A., and Puccetti, L. (2006). Pro-inflammatory/anti-inflammatory cytokine imbalance in acute coronary syndromes. Clin Exp Med 6, 38-44.

Pinderski, L.J., Fischbein, M.P., Subbanagounder, G., Fishbein, M.C., Kubo, N., Cheroutre, H., Curtiss, L.K., Berliner, J.A., and Boisvert, W.A. (2002). Overexpression of interleukin-10 by activated T lymphocytes inhibits atherosclerosis in LDL receptordeficient Mice by altering lymphocyte and macrophage phenotypes. Circ Res 90, 1064-1071.

Pinderski Oslund, L.J., Hedrick, C.C., Olvera, T., Hagenbaugh, A., Territo, M., Berliner, J.A., and Fyfe, A.I. (1999). Interleukin-10 blocks atherosclerotic events in vitro and in vivo. Arterioscler Thromb Vasc Biol 19, 2847-2853.

Ramani, M., Ollivier, V., Khechai, F., Vu, T., Ternisien, C., Bridey, F., and de Prost, D. (1993). Interleukin-10 inhibits endotoxin-induced tissue factor mRNA production by human monocytes. FEBS Lett 334, 114-116.

Ricote, M., Li, A.C., Willson, T.M., Kelly, C.J., and Glass, C.K. (1998). The peroxisome proliferator-activated receptor-gamma is a negative regulator of macrophage activation. Nature 391, 79-82.

Ross, R. (1999). Atherosclerosis--an inflammatory disease. N Engl J Med 340, 115-126.

Rubic, T., and Lorenz, R.L. (2006). Downregulated CD36 and oxLDL uptake and stimulated ABCA1/G1 and cholesterol efflux as anti-atherosclerotic mechanisms of interleukin-10. Cardiovasc Res 69, 527-535. 
Saren, P., Welgus, H.G., and Kovanen, P.T. (1996). TNF-alpha and IL-1beta selectively induce expression of 92-kDa gelatinase by human macrophages. J Immunol 157, 4159-4165.

Seder, R.A., Gazzinelli, R., Sher, A., and Paul, W.E. (1993). Interleukin 12 acts directly on CD4+ T cells to enhance priming for interferon gamma production and diminishes interleukin 4 inhibition of such priming. Proc Natl Acad Sci U S A 90, 10188-10192.

Seyrek, N., Karayaylali, I., Balal, M., Paydas, S., Aikimbaev, K., Cetiner, S., and Seydaoglu, G. (2005). Is there any relationship between serum levels of interleukin-10 and atherosclerosis in hemodialysis patients? Scand J Urol Nephrol 39, 405-409.

Sieling, P.A., Wang, X.H., Gately, M.K., Oliveros, J.L., McHugh, T., Barnes, P.F., Wolf, S.F., Golkar, L., Yamamura, M., Yogi, Y., et al. (1994). IL-12 regulates T helper type 1 cytokine responses in human infectious disease. J Immunol 153, 3639-3647.

Singh, U., Devaraj, S., Dasu, M.R., Ciobanu, D., Reusch, J., and Jialal, I. (2006). C-reactive protein decreases interleukin-10 secretion in activated human monocyte-derived macrophages via inhibition of cyclic AMP production. Arterioscler Thromb Vasc Biol 26, 2469-2475.

Smith, E., Prasad, K.M., Butcher, M., Dobrian, A., Kolls, J.K., Ley, K., and Galkina, E. (2010). Blockade of interleukin-17A results in reduced atherosclerosis in apolipoprotein Edeficient mice. Circulation 121, 1746-1755.

Staels, B. (2005). PPARgamma and atherosclerosis. Curr Med Res Opin 21 Suppl 1, S13-20.

Tabas, I. (2010). Macrophage death and defective inflammation resolution in atherosclerosis. Nat Rev Immunol 10, 36-46.

Taleb, S., Romain, M., Ramkhelawon, B., Uyttenhove, C., Pasterkamp, G., Herbin, O., Esposito, B., Perez, N., Yasukawa, H., Van Snick, J., et al. (2009). Loss of SOCS3 expression in $\mathrm{T}$ cells reveals a regulatory role for interleukin-17 in atherosclerosis. J Exp Med 206, 2067-2077.

Taleb, S., Tedgui, A., and Mallat, Z. (2010). Adaptive T cell immune responses and atherogenesis. Curr Opin Pharmacol 10, 197-202.

Tall, A.R., Yvan-Charvet, L., Terasaka, N., Pagler, T., and Wang, N. (2008). HDL, ABC transporters, and cholesterol efflux: implications for the treatment of atherosclerosis. Cell Metab 7, 365-375.

Tedgui, A., and Mallat, Z. (2006). Cytokines in atherosclerosis: pathogenic and regulatory pathways. Physiol Rev 86, 515-581.

Terkeltaub, R.A. (1999). IL-10: An "immunologic scalpel" for atherosclerosis? Arterioscler Thromb Vasc Biol 19, 2823-2825.

Teupser, D., Stein, O., Burkhardt, R., Nebendahl, K., Stein, Y., and Thiery, J. (1999). Scavenger receptor activity is increased in macrophages from rabbits with low atherosclerotic response: studies in normocholesterolemic high and low atherosclerotic response rabbits. Arterioscler Thromb Vasc Biol 19, 1299-1305.

Trompet, S., Pons, D., AJ, D.E.C., Slagboom, P., Shepherd, J., Blauw, G.J., Murphy, M.B., Cobbe, S.M., Bollen, E.L., Buckley, B.M., et al. (2007). Genetic variation in the interleukin-10 gene promoter and risk of coronary and cerebrovascular events: the PROSPER study. Ann N Y Acad Sci 1100, 189-198.

Tziakas, D.N., Chalikias, G.K., Kaski, J.C., Kekes, A., Hatzinikolaou, E.I., Stakos, D.A., Tentes, I.K., Kortsaris, A.X., and Hatseras, D.I. (2007). Inflammatory and anti- 
inflammatory variable clusters and risk prediction in acute coronary syndrome patients: a factor analysis approach. Atherosclerosis 193, 196-203.

Uyemura, K., Demer, L.L., Castle, S.C., Jullien, D., Berliner, J.A., Gately, M.K., Warrier, R.R., Pham, N., Fogelman, A.M., and Modlin, R.L. (1996). Cross-regulatory roles of interleukin (IL)-12 and IL-10 in atherosclerosis. J Clin Invest 97, 2130-2138.

van der Poll, T., Jansen, J., Levi, M., ten Cate, H., ten Cate, J.W., and van Deventer, S.J. (1994). Regulation of interleukin 10 release by tumor necrosis factor in humans and chimpanzees. J Exp Med 180, 1985-1988.

Van Eck, M., De Winther, M.P., Herijgers, N., Havekes, L.M., Hofker, M.H., Groot, P.H., and Van Berkel, T.J. (2000). Effect of human scavenger receptor class A overexpression in bone marrow-derived cells on cholesterol levels and atherosclerosis in ApoEdeficient mice. Arterioscler Thromb Vasc Biol 20, 2600-2606.

van Es, T., van Puijvelde, G.H., Ramos, O.H., Segers, F.M., Joosten, L.A., van den Berg, W.B., Michon, I.M., de Vos, P., van Berkel, T.J., and Kuiper, J. (2009). Attenuated atherosclerosis upon IL-17R signaling disruption in LDLr deficient mice. Biochem Biophys Res Commun 388, 261-265.

van Tits, L.J., Stienstra, R., van Lent, P.L., Netea, M.G., Joosten, L.A., and Stalenhoef, A.F. (2011). Oxidized LDL enhances pro-inflammatory responses of alternatively activated M2 macrophages: a crucial role for Kruppel-like factor 2. Atherosclerosis 214, 345-349.

Von Der Thusen, J.H., Kuiper, J., Fekkes, M.L., De Vos, P., Van Berkel, T.J., and Biessen, E.A. (2001). Attenuation of atherogenesis by systemic and local adenovirus-mediated gene transfer of interleukin-10 in LDLr-/- mice. FASEB J 15, 2730-2732.

Waehre, T., Halvorsen, B., Damas, J.K., Yndestad, A., Brosstad, F., Gullestad, L., Kjekshus, J., Froland, S.S., and Aukrust, P. (2002). Inflammatory imbalance between IL-10 and TNFalpha in unstable angina potential plaque stabilizing effects of IL-10. Eur J Clin Invest 32, 803-810.

Wang, N., and Tall, A.R. (2003). Regulation and mechanisms of ATP-binding cassette transporter A1-mediated cellular cholesterol efflux. Arterioscler Thromb Vasc Biol 23, 1178-1184.

Wang, P., Wu, P., Siegel, M.I., Egan, R.W., and Billah, M.M. (1995). Interleukin (IL)-10 inhibits nuclear factor kappa B (NF kappa B) activation in human monocytes. IL-10 and IL-4 suppress cytokine synthesis by different mechanisms. J Biol Chem 270, 9558-9563.

Wang, X., Collins, H.L., Ranalletta, M., Fuki, I.V., Billheimer, J.T., Rothblat, G.H., Tall, A.R., and Rader, D.J. (2007). Macrophage ABCA1 and ABCG1, but not SR-BI, promote macrophage reverse cholesterol transport in vivo. J Clin Invest 117, 2216-2224.

Weber, C., Zernecke, A., and Libby, P. (2008). The multifaceted contributions of leukocyte subsets to atherosclerosis: lessons from mouse models. Nat Rev Immunol 8, 802815.

Whitman, S.C., Rateri, D.L., Szilvassy, S.J., Cornicelli, J.A., and Daugherty, A. (2002). Macrophage-specific expression of class A scavenger receptors in LDL receptor(-/-) mice decreases atherosclerosis and changes spleen morphology. J Lipid Res 43, 1201-1208.

Witztum, J.L., and Steinberg, D. (2001). The oxidative modification hypothesis of atherosclerosis: does it hold for humans? Trends Cardiovasc Med 11, 93-102. 
Woollard, K.J., and Geissmann, F. (2010). Monocytes in atherosclerosis: subsets and functions. Nat Rev Cardiol 7, 77-86.

Woszczek, G., Chen, L.Y., Nagineni, S., and Shelhamer, J.H. (2008). IL-10 inhibits cysteinyl leukotriene-induced activation of human monocytes and monocyte-derived dendritic cells. J Immunol 180, 7597-7603.

Wynn, T.A. (2004). Fibrotic disease and the $\mathrm{T}(\mathrm{H}) 1 / \mathrm{T}(\mathrm{H}) 2$ paradigm. Nat Rev Immunol 4, 583-594.

Ye, D., Lammers, B., Zhao, Y., Meurs, I., Van Berkel, T.J., and Van Eck, M. (2011). ATPbinding cassette transporters A1 and G1, HDL metabolism, cholesterol efflux, and inflammation: important targets for the treatment of atherosclerosis. Curr Drug Targets 12, 647-660.

Yoshioka, T., Okada, T., Maeda, Y., Ikeda, U., Shimpo, M., Nomoto, T., Takeuchi, K., Nonaka-Sarukawa, M., Ito, T., Takahashi, M., et al. (2004). Adeno-associated virus vector-mediated interleukin-10 gene transfer inhibits atherosclerosis in apolipoprotein E-deficient mice. Gene Ther 11, 1772-1779.

Yvan-Charvet, L., Ranalletta, M., Wang, N., Han, S., Terasaka, N., Li, R., Welch, C., and Tall, A.R. (2007). Combined deficiency of ABCA1 and ABCG1 promotes foam cell accumulation and accelerates atherosclerosis in mice. J Clin Invest 117, 3900-3908.

Zhao, Y., Van Berkel, T.J., and Van Eck, M. (2010). Relative roles of various efflux pathways in net cholesterol efflux from macrophage foam cells in atherosclerotic lesions. Curr Opin Lipidol 21, 441-453.

Zhou, X., Paulsson, G., Stemme, S., and Hansson, G.K. (1998). Hypercholesterolemia is associated with a T helper (Th) 1/Th2 switch of the autoimmune response in atherosclerotic apo E-knockout mice. J Clin Invest 101, 1717-1725.

Zimmerman, M.A., Reznikov, L.L., Raeburn, C.D., and Selzman, C.H. (2004). Interleukin-10 attenuates the response to vascular injury. J Surg Res 121, 206-213. 


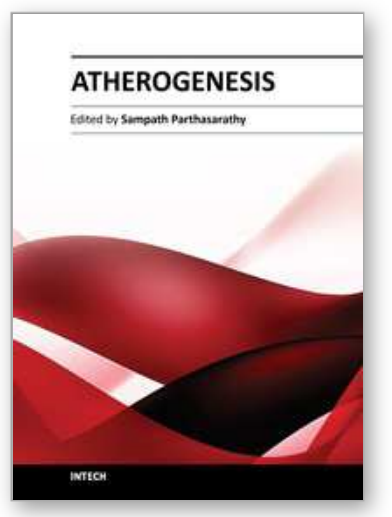

\author{
Atherogenesis \\ Edited by Prof. Sampath Parthasarathy
}

ISBN 978-953-307-992-9

Hard cover, 570 pages

Publisher InTech

Published online 11, January, 2012

Published in print edition January, 2012

This monograph will bring out the state-of-the-art advances in the dynamics of cholesterol transport and will address several important issues that pertain to oxidative stress and inflammation. The book is divided into three major sections. The book will offer insights into the roles of specific cytokines, inflammation, and oxidative stress in atherosclerosis and is intended for new researchers who are curious about atherosclerosis as well as for established senior researchers and clinicians who would be interested in novel findings that may link various aspects of the disease.

\title{
How to reference
}

In order to correctly reference this scholarly work, feel free to copy and paste the following:

Xinbing Han and William A. Boisvert (2012). The Role of IL-10 in Atherosclerosis, Atherogenesis, Prof. Sampath Parthasarathy (Ed.), ISBN: 978-953-307-992-9, InTech, Available from:

http://www.intechopen.com/books/atherogenesis/the-role-of-il-10-in-atherosclerosis

\section{INTECH}

open science | open minds

\section{InTech Europe}

University Campus STeP Ri

Slavka Krautzeka 83/A

51000 Rijeka, Croatia

Phone: +385 (51) 770447

Fax: +385 (51) 686166

www.intechopen.com

\section{InTech China}

Unit 405, Office Block, Hotel Equatorial Shanghai

No.65, Yan An Road (West), Shanghai, 200040, China 中国上海市延安西路65号上海国际贵都大饭店办公楼405单元

Phone: +86-21-62489820

Fax: $+86-21-62489821$ 
(C) 2012 The Author(s). Licensee IntechOpen. This is an open access article distributed under the terms of the Creative Commons Attribution 3.0 License, which permits unrestricted use, distribution, and reproduction in any medium, provided the original work is properly cited. 